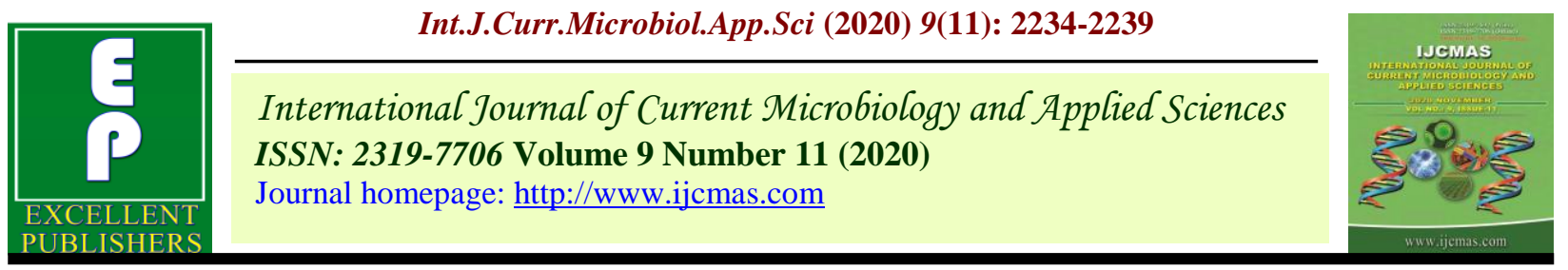

Original Research Article

https://doi.org/10.20546/ijcmas.2020.911.268

\title{
Efficacy of Herbicides on Morphological Parameters of Gladiolus (Gladiolus grandiflora L.) under Hill Zone of Karnataka
}

\author{
Anand Burud*, S. Y. Chandrashekar, D. Thippesha, M. Shivaprasad, \\ M. Ganapathi and Veena Goni
}

Department of Floriculture and Landscape Architecture, College of Horticulture, Mudigere, University of Agricultural and Horticultural Sciences, Shivamogga, Karnataka, India

*Corresponding author

\section{A B S T R A C T}

Keywords

Gladiolus,

Weed, Herbicide

Article Info

Accepted:

17 October 2020

Available Online:

10 November 2020
The investigation on the efficacy of pre-emergent herbicides on morphological parameters of gladiolus (Gladiolus grandiflora L.) under hill zone of Karnataka was conducted at experimental block in the Department of Floriculture and Landscape Architecture, College of Horticulture, Mudigere (under University of Agricultural and Horticultural Sciences, Shivamogga), during 2019-2020.The experiment comprises of twelve treatments replicated thrice in Randomized Complete Block Design. The results revealed that the maximum sprouting per cent (100 per cent), number of shoots /corm $(1.83)$, plant height $(70.50 \mathrm{~cm})$ recorded in weed free treatment. While the maximum number of leaves per plant (10.20), leaf area, leaf area index (1023.93 $\mathrm{cm}^{2}$ and 1.72 , respectively), chlorophyll-a, chlorophyll$\mathrm{b}$ and total chlorophyll content in leaves $(1.57,0.79$ and $2.36 \mathrm{mg} / \mathrm{g}$, respectively) recorded with pre-emergence application of pendimethalin at $1.0 \mathrm{~kg}$ a.i./ha. Whereas the minimum sprouting per cent (90.89per cent), number of shoots /corm $(1.26)$, plant height $(51.20 \mathrm{~cm})$, number of leaves $(5.70)$, leaf area, leaf area index $\left(403.99 \mathrm{~cm}^{2}\right.$ and 0.71 , respectively), chlorophyll-a, chlorophyll-b and total chlorophyll content in leaves $(0.82,0.28$ and 1.10 $\mathrm{mg} / \mathrm{g}$, respectively) are observed in weedy check condition.

\section{Introduction}

Gladiolus (Gladiolus grandiflorus), otherwise known as "Sword Lily" or queen of the bulbous plants is a popular ornamental bulbous plant originated in South Africa. Taxonomically placed under monocot family Iridaceae, (Lepcha et al., 2007). Iridaceae family includes perennial, rhizomatous bulbous plants distributed globally with greatest diversity in South Africa (Pragya et $a l, 2010)$. The genus gladiolus is comprised of about 265 species and is one of the largest genera of family Iridaceae. The Cape of Good Hope (South Africa) is considered to be the centre of diversity for the genus gladiolus. It is distributed throughout the region of tropical Africa, Madagascar, Arabian Peninsula, Mediterranean basin, Europe and Asia, including Iran and Afghanistan. In gladiolus, menaces of weeds are well known. The losses caused by weeds exceed the losses caused by 
any other category of agricultural pests. Unnecessary interference of weeds results in several unintended consequences such as decrease in yields, increase production costs, reduction in quality, increased threat of serious insects and disease problems and many more.

Considering all these factors, in the most highly mechanised era of $21^{\text {st }}$ century, choosing a chemical weed control gives new hopes that it can be done efficiently with minimal cost in gladiolus. Weed control using herbicides is one of the best alternatives.

\section{Materials and Methods}

The experiment was carried out at the experimental block of Department of Floriculture and Landscape Architecture, College of Horticulture, Mudigere (under University of Agricultural and Horticultural Sciences, Shivamogga), during 2019-2020. The experiment was laid out in Randomized Complete Block Design (RCBD) with 12 treatments viz., $\mathrm{T}_{1}$-atrazine @ $1.0 \mathrm{~kg}$ a.i./ha, $\mathrm{T}_{2}$-atrazine@1.5 kg a.i./ha, $\mathrm{T}_{3}$-metribuzin @ $0.25 \mathrm{~kg}$ a.i./ha, $\mathrm{T}_{4}$-metribuzin @ $0.5 \mathrm{~kg}$ a.i./ha, T5-butachlor @ $1.0 \mathrm{~kg}$ a.i./ha, $\mathrm{T}_{6}$ butachlor@1.5 kg a.i./ha, T7-pendimethalin @ $0.75 \mathrm{~kg}$ a.i./ha, $\mathrm{T}_{8}$-pendimethalin @ $1.0 \mathrm{~kg}$ a.i./ha, T9-oxyfluorfen @ $0.5 \mathrm{~kg}$ a.i./ ha, $\mathrm{T}_{10^{-}}$ oxyfluorfen @ $1.0 \mathrm{~kg}$ a.i./ha, $\mathrm{T}_{11}$-weedy check, $\mathrm{T}_{12}$-weed free and three replications. Healthy and uniform corms measuring about 3-4 cm are selected for planting. Before planting corms are treated with thiourea at $1000 \mathrm{ppm}$ for half an hour and they are planted at a spacing of $30 \mathrm{~cm} \times 20 \mathrm{~cm}$ on flat beds and light irrigation was given immediately after planting followed by spraying of herbicides two days after planting. The crop was fertilized with recommended dose of fertilizers, i.e., $\mathrm{N}, \mathrm{P}$ and $\mathrm{K}$ @ 100:60:60 kg per ha in the form of urea, SSP and MOP.

\section{Results and Discussion}

Results pertaining to effect of different herbicides on morphological parameters of gladiolusare depicted in table 1,2 and 3.

The maximum sprouting per cent and number of shoots per corm was noticed in the treatment weed free followed by pendimethalin $(1.0 \mathrm{~kg}$ a.i./ha). This may be due to weed free treatment reduced the weed flora there by improved nutrient availability and uptake which led to increased sprouting per cent in gladiolus.

Bhat et al., (2013) reported that among the treatments, weed free and pendimethalin 1.5 $\mathrm{kg} \mathrm{ha}^{-1}$ showed better results with sprouting per cent and number of shoots per corm in gladiolus and Swaroop et al., (2014) found the similar results in gladiolus (Table 1).

Among weed control treatments, weed free $\left(\mathrm{T}_{12}\right)$ recorded maximum plant height and was followed by pendimethalin at $(1.0 \mathrm{~kg}$ a.i./ha) and $(0.75 \mathrm{~kg}$ a.i.ha) recorded maximum plant height during various stages of crop growth. This may be due to less weed competition during the critical growth period and better availability of nutrients, moisture, sunlight and space for crop growth. Increase in plant height was associated with rapid meristematic activity, probably due to rapid cell division and elongation during the tender growth period (Sharova et al, 1977).

Removal of weeds during early stages of crop growth resulted in reduced weed competition and enabled the crop to grow taller. At all stages of crop growth, weedy check resulted in the plants of short stature, which might be due to competition extended by the weeds. This is in conformity with the findings of Koutepas (1982), Pal and Das (1990) and Basavaraju et al., (1992) (Fig. 1). 
Table.1 Effect of different herbicides on morphological parameters in gladiolus

\begin{tabular}{|c|c|c|c|c|}
\hline Treatment details & $\begin{array}{l}\text { Sprouting } \\
\text { per cent }\end{array}$ & $\begin{array}{l}\text { No. of shoots } \\
\text { per corm }\end{array}$ & $\begin{array}{c}\text { Plant } \\
\text { height(cm) }\end{array}$ & No. of leaves \\
\hline $\mathrm{T}_{1}$ - Atrazine @ $1.0 \mathrm{~kg}$ a.i./ha & 96.66 & 1.51 & 60.50 & 6.30 \\
\hline $\mathrm{T}_{2}$ - Atrazine @ $1.5 \mathrm{~kg}$ a.i./ha & 95.55 & 1.42 & 63.20 & 6.20 \\
\hline $\mathrm{T}_{3^{-}}$Metribuzin @0.25 kg a.i./ha & 92.22 & 1.39 & 57.10 & 8.20 \\
\hline 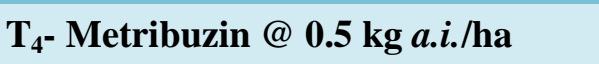 & 93.33 & 1.46 & 55.20 & 7.40 \\
\hline T5- Butachlor @1.0 kg a.i./ha & 96.66 & 1.33 & 55.00 & 7.30 \\
\hline T6- Butachlor @1.5 kg a.i./ha & 92.77 & 1.31 & 53.70 & 6.80 \\
\hline $\mathrm{T}_{7}$ - Pendimethalin @0.75 kg a.i./ha & 97.77 & 1.64 & 65.40 & 9.00 \\
\hline T - Pendimethalin@1.0 kg a.i./ha & 98.88 & 1.76 & 68.30 & 10.20 \\
\hline $\mathrm{T}_{9^{-}}$Oxyfluorfen @0.5 kg a.i./ha & 90.89 & 1.41 & 58.30 & 7.10 \\
\hline$T_{10^{-}}$Oxyfluorfen@1.0 kg a.i./ha & 94.44 & 1.58 & 58.70 & 7.00 \\
\hline$T_{11}$-Weedy check & 90.89 & 1.26 & 51.20 & 5.70 \\
\hline$T_{12}$-Weed free & 100.00 & 1.83 & 70.50 & 7.20 \\
\hline S.Em \pm & 3.13 & 0.07 & 1.95 & 0.45 \\
\hline CD@ $9 \%$ & 9.17 & 0.20 & 5.72 & 1.32 \\
\hline
\end{tabular}

Table.2 Effect of different herbicides on leaf area and leaf area index in gladiolus

\begin{tabular}{|c|c|c|}
\hline Treatment & Leaf area $\left(\mathrm{cm}^{2}\right)$ & Leaf area index (LAI) \\
\hline T1- Atrazine @ $1.0 \mathrm{~kg}$ a.i./ha & 422.87 & 0.87 \\
\hline $\mathrm{T}_{2}$ - Atrazine @ $1.5 \mathrm{~kg}$ a.i./ha & 483.32 & 1.03 \\
\hline T3- Metribuzin@0.25 kga.i./ha & 815.90 & 1.43 \\
\hline T/4-Metribuzin @0.5 kg a.i./ha & 856.42 & 1.57 \\
\hline $\mathrm{T}_{5}$ - Butachlor @ 1.0 kg a.i./ha & 521.38 & 1.21 \\
\hline T6-Butachlor@1.5 kg a.i./ha & 575.01 & 1.38 \\
\hline T & 941.56 & 1.69 \\
\hline$T_{8}$-Pendimethalin@1.0 kg a.i./ha & 1023.93 & 1.72 \\
\hline T9- Oxyfluorfen@0.5 kga.i./ha & 621.04 & 1.32 \\
\hline $\mathrm{T}_{10^{-}}$Oxyfluorfen @ $1.0 \mathrm{~kg} a . i . / \mathrm{ha}$ & 684.23 & 1.37 \\
\hline$T_{11}$-Weedy check & 403.99 & 0.71 \\
\hline$T_{12}$-Weed free & 852.37 & 1.45 \\
\hline S.Em \pm & 22.25 & 0.05 \\
\hline CD@ 5\% & 65.25 & 0.14 \\
\hline
\end{tabular}


Table.3 Effect of different herbicides on bio chemical parameters in gladiolus

\begin{tabular}{|c|c|c|c|}
\hline Treatment & $\begin{array}{l}\text { Chlorophyll- } \\
\text { a(mg/g of fresh } \\
\text { weight) }\end{array}$ & $\begin{array}{l}\text { Chlorophyll- } \\
\text { b(mg/g of fresh } \\
\text { weight) }\end{array}$ & $\begin{array}{l}\text { Total chlorophyll } \\
\text { content(mg/g of } \\
\text { fresh weight) }\end{array}$ \\
\hline T1-Atrazine@1.0 kg a.i./ha & 0.97 & 0.35 & 1.32 \\
\hline $\mathrm{T}_{2-}$ Atrazine @ $1.5 \mathrm{~kg}$ a.i./ha & 0.89 & 0.38 & 1.27 \\
\hline $\mathrm{T}_{3}$ - Metribuzin @0.25 kg a.i./ha & 1.49 & 0.45 & 1.97 \\
\hline $\mathbf{T}_{4}$ - Metribuzin @0.5 kg a.i./ha & 1.41 & 0.44 & 1.85 \\
\hline $\mathbf{T}_{5}$ - Butachlor @ $1.0 \mathrm{~kg}$ a.i./ha & 1.37 & 0.37 & 1.74 \\
\hline 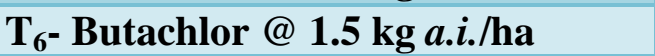 & 1.02 & 0.41 & 1.43 \\
\hline T7- Pendimethalin @ 0.75 kg a.i./ha & 1.52 & 0.70 & 2.19 \\
\hline T8- Pendimethalin @1.0 kg a.i./ha & 1.57 & 0.79 & 2.36 \\
\hline T9- Oxyfluorfen@0.5 kga.i./ha & 1.21 & 0.40 & 1.61 \\
\hline$T_{10^{-}}$Oxyfluorfen @ 1.0 kg a.i./ha & 1.09 & 0.43 & 1.52 \\
\hline$T_{11}$-Weedy check & 0.82 & 0.28 & 1.10 \\
\hline$T_{12}$-Weed free & 1.42 & 0.70 & 2.12 \\
\hline S.Em \pm & 0.05 & 0.03 & 0.07 \\
\hline CD@ $9 \%$ & 0.14 & 0.10 & 0.20 \\
\hline
\end{tabular}

Fig.1 Effect of different herbicides on morphological parameters in gladiolus

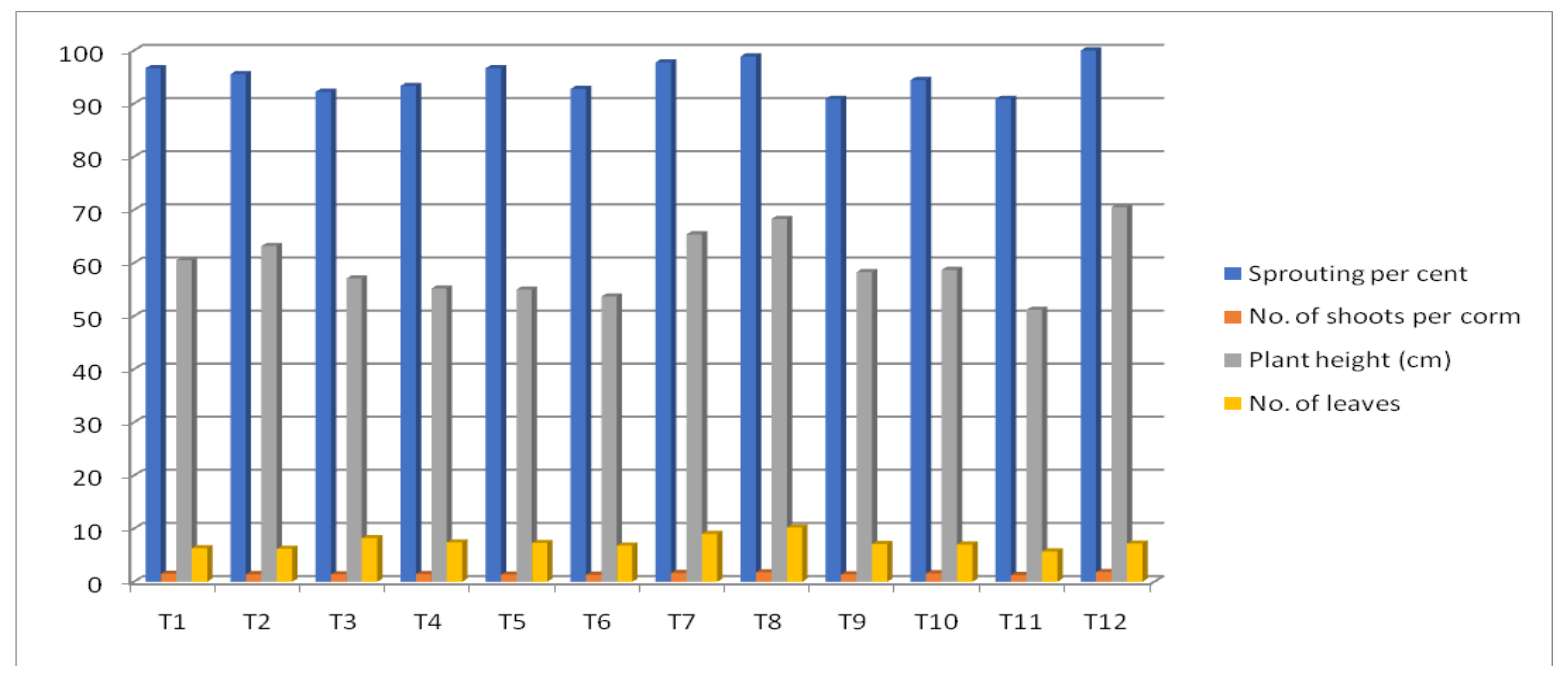

Among the weed control treatments, over pendimethalin $(1.0 \mathrm{~kg}$ a.i./ha $)$ recorded significantly maximum number of leaves than other treatments at 30, 45 and 60 days after planting. This might be due to better control of weeds at early stages of crop growth which coincided with critical crop growth period and weed competition followed by reduction in competition for nutrients, moisture and sunlight which improved the crop growth in terms of number of leaves per plant. These results are in conformity with the Shalini and Patil (2004) in gerbera. It was concluded that weeds should be controlled before three leaf stage of gladiolus crop to enable the production of good quality of cut flower Cheong et al., (2000) (Table 1). 
During all the stages of crop growth, the maximum leaf area was recorded with pendimethalin (1.0 kg a.i./ha) at 60 days after planting. Pendimethalin is an effective herbicide for gladiolus crop (Mishra, 1997). This may be due to production of more number of long and wider leaves and accelerated relative growth which was controlled by cell division and cell elongation, which ultimately led to higher leaf area. This may be due to availability of nutrients and soil moisture. Minimum leaf area was recorded in weedy check treatment at all stages of crop growth due to severe weed competition for growth factors of the crop. These results are in conformity with the findings of Pitt et al., (1981), Anandamurthy and Narayanagowda (1993) and Shalini and Patil in gerbera (2004) (Table 2).

During early stages of crop growth, the maximum leaf area index was recorded with pendimethalin $(0.75 \mathrm{~kg}$ a.i./ha), while during later stages of crop growth, the maximum leaf area index was recorded with pendimethalin (1.0 kg a.i./ha). This might be due to production of more number of long and wider leaves and accelerated relative growth which was controlled by cell division and cell elongation, which ultimately led to maximum leaf area index. These results are in conformity with the findings of Pitt et al., (1981), Anandamurthy and Narayanagowda (1993) and Shalini and Patil (2004).

Significantly maximum chlorophyll 'a', chlorophyll ' $b$ ' and total chlorophyll content in leaves was recorded in the treatment pendimethalin $(1.0 \mathrm{~kg}$ a.i./ha). This increase in chlorophyll content in leaves may be due to increase in availability and uptake of more water and essential nutrients during critical growth stages of crop which led to more accumulation of photo assimilates in leaves and also might be due to pendimethalin reduced the competition for space and light by increasing weed control efficiency (Table 3).

\section{References}

Anandamurthy, G. M. and Narayanagowda, J. V., 1993. Role of pre-emergence herbicides on the life of cut tuberose flowers. Current Research. 22: 161162.

Basavaraju, C., Gowda, J. V. N. and Muniyappa, T. V., 1992. Effect of preemergent herbicides on yield in China aster. Current Research. 21: 50-51.

Bhat, Z. A. Sheiakh, M. Q and Siddique, M. A., 2013. Effect of chemicals on weed control on vegetative, reproductive and yield parameters in gladiolus (Gladiolus hybridus L.) cv. Buff beauty. Indian Journal of Horticulture. 3: 107-108.

Cheong, D., Kim, J. and Park, H., 2000. Effects of weeding time growth time on growth and flowering of Gladiolus 'Spic \& Span' (Korean). Journal of Korean Society for Horticulural Science. 41(2): 201-206.

Koutepas, N. G., 1982. Effect of weeds and herbicides on qualitative and quantitative characteristics of gladiolus. Zizaniologia. 1: 39-42.

Lepcha, B., Nautiyal, M. C. and Rao, V. K., 2007. Variability studies in gladiolus under mid hill conditions of Uttarakhand. Journal of Ornamental Horticulture. 10(3): 169-172.

Mishra, H. P., 1997. Evaluation of small flowered varieties of gladiolus for calcareous belt of North Bihar. Indian Journal of Horticulture. 56(2): 184188.

Pitt, H. B., Hiwale, B. G., Warke, D. C. and Patil, V. K., 1981. Effect of linuron on the weed control in gladiolus, $c v$. Grandiflora. In: Abstract of Papers Presented at Annual Conference Indian Society Weed Science, 
Marathawada Agriculture University, Parbhani, Maharashtra, India. pp. 32.

Pragya, R., Bhat, K. V., Misra, R. L., Singh, S. K. and Ranjan, J. K., 2010. Genetic relationships of gladiolus cultivars inferred from fluorescence based AFLP markers. Science Horticulture. 123: 562-567.

Shalini, M. and Patil, V. S., 2004. Effect of integrated weed management practices on Vegetative, reproductive and yield parameters in gerbera (Gerbera jamesonii $\mathrm{H}$. Bolus). Journal of
Ornamental Horticulture.7(3): 144-147 Sharova, N. L., Rybak, Y. G. and Marins, W. E., 1977. Development of gladiolus under the influence of micronutrients. refractivnyi zhurnal.6(55): 1093.

Swaroop, k., Jankiram, T. and Das, T. K., 2014.Flowering and corm yield of gladiolus $c v$. jyotsna as Influenced by pre-emergence application of different herbicides. International Journal of Tropical Agriculture. 32(1- 2): 89-94.

\section{How to cite this article:}

Anand Burud, S. Y. Chandrashekar, D. Thippesha, M. Shivaprasad, M. Ganapathi and Veena Goni. 2020. Efficacy of Herbicides on Morphological Parameters of Gladiolus (Gladiolus grandiflora L.) under Hill Zone of Karnataka. Int.J.Curr.Microbiol.App.Sci. 9(11): 2234-2239. doi: https://doi.org/10.20546/ijcmas.2020.911.268 